\title{
LONG-TERM GLACIER MASS-BALANCE INVESTIGATIONS IN SVALBARD, 1950-88
}

by

Jon Ove Hagen and Olav Liestøl

(Norsk Polarinstitutt, P.O. Box 158, N-1330 Oslo Lufthavn, Norway)

\section{ABSTRACT}

Mass-balance investigations on glaciers in Svalbard at high latitudes $\left(78^{\circ} \mathrm{N}\right)$ show that the ice masses have been steadily decreasing during the period 1950-88. Detailed annual observations have been carried out on Brøggerbreen since 1966 and Lovénbreen since 1967. The mean specific net balances are -0.46 and $-0.37 \mathrm{~m} \mathrm{year}^{-1}$ water equivalent respectively. Only one year had positive net balance in this period. The cumulative mass lost in the period is then more than $10 \%$ of the volume in 1967. Zero net balance would be obtained if the summer temperature was lowered about $1{ }^{\circ} \mathrm{C}$ or if the winter precipitation increased about $50 \%$ There is a strong correlation between the net mass balance and the height of the equilibrium-line altitude (ELA). Because of the high amount of superimposed ice (10-30\% of winter balance) stake readings are necessary to find the ELA. There is no sign of climatic warming through increased melting. The trend analysis of the data from the last 20 years shows stable conditions with a slight increase of the winter balance. The net balance is then slightly increasing and thus less negative than 20 years ago.

\section{INTRODUCTION}

Mass-balance data from extreme high latitudes are sparse. According to the World Glacier Monitoring Service (1988) statistics for $1980-85$ only Meighen Island $\left(79^{\circ} 57^{\prime} \mathrm{N}\right)$ and Devon Island $\left(75^{\circ} 25^{\prime} \mathrm{N}\right)$ ice caps in north Canada and Brøggerbreen and Lovénbreen $\left(78^{\circ} 53^{\prime} \mathrm{N}\right)$ in Svalbard are measured north of $70^{\circ} \mathrm{N}$. In this paper results of the long time series of measurements in Svalbard are presented. Since 1967 detailed annual mass-balance measurements using the direct glaciological method (stakes and pits) have been carried out on Brøggerbreen and Lovénbreen in the Kongsf jord area in the north-west of Spitsbergen (Fig. 1). On Finsterwalderbreen in central south Spitsbergen net mass balance has been measured every second year since 1950 . Soviet mass-balance investigations have been carried out on different glaciers mainly in central Spitsbergen during the period 1973-86.

\section{SVALBARD}

Svalbard is a group of islands between lat. $76^{\circ} \mathrm{N}$ and $81^{\circ} \mathrm{N}$, and long. $10^{\circ} \mathrm{E}$ and $35^{\circ} \mathrm{E}$ (Fig. 1). The total area is about $63000 \mathrm{~km}^{2} ; 60 \%$ is covered by glaciers. In the western areas of the archipelago small cirque glaciers are numerous. In central parts the glaciers mainly consist of large continuous ice masses divided into individual ice streams by mountain ridges and nunatak areas. In the eastern areas, where the landscape is fairly flat, large ice caps are located.

Ice-free land areas have continuous permafrost with thickness varying from less than $100 \mathrm{~m}$ near sea-level up to $500 \mathrm{~m}$ in the higher mountains (Liestøl, 1977).

The glaciers are polar and subpolar. Unfrozen taliks are found below higher and central parts of many glaciers. In front of these glaciers water escapes during the whole winter and large ice masses are formed.

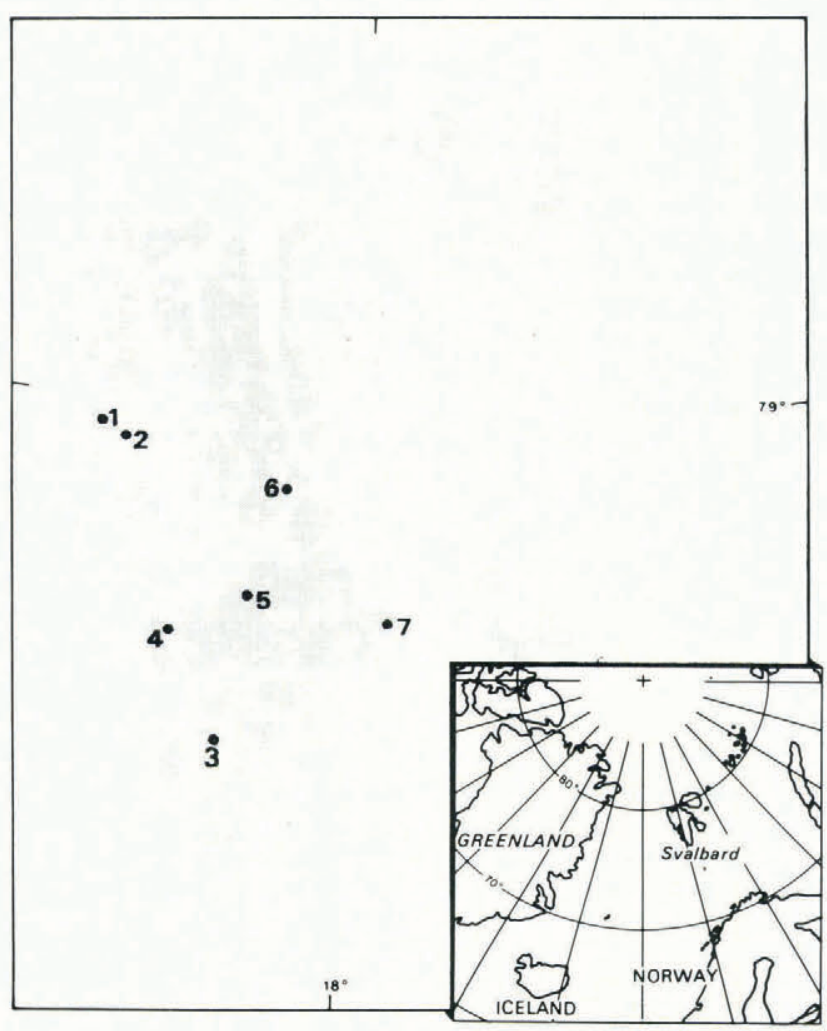

Fig. 1. Location map of Svalbard showing glaciers where mass-balance studies have been carried out. Glaciercovered areas are shaded. 1. Brøggerbreen and Lovénbreen; 2. Kongsvegen; 3. Finsterwalderbreen; 4. Vöringbreen; 5. Longyearbreen and Bogerbreen; 6 . Bertilbreen; 7. Daudbreen.

Surging glaciers are very frequent; probably $90 \%$ of the glaciers in Svalbard are of the so-called surge-type.

The glaciers were close to their late Holocene (Little Ice Age) maximum extension as late as the end of the 19th or beginning of the 20th century. As in the rest of the world, a general shrinkage of the glaciers has occurred during the first half of the 20th century.

Temperature records are available from Svalbard since 1912. At $\mathrm{Ny}$-Ålesund weather station close to the investigated area the mean year temperature is $-6.0^{\circ} \mathrm{C}$ (1971-88) The summer months have mean temperatures above zero, June $2.1{ }^{\circ} \mathrm{C}$, July $5.2{ }^{\circ} \mathrm{C}$, August $4.1^{\circ} \mathrm{C}$ and September $0.1{ }^{\circ} \mathrm{C}$. Even the highest areas of the glaciers at about $800 \mathrm{~m}$ a.s.l. have some days with temperatures above zero and surface snow melting.

\section{MASS-BALANCE INVESTIGATIONS}

In 1950 the Norwegian Polar Research Institute started the first systematic mass-balance studies on Finster- 
walderbreen on the south side of Van Keulenfjorden (Fig. 1). There were expeditions by the Polar Institute to Svalbard every second year from 1950 to 1966. Therefore we only have net mass-balance data given as mean values for every second year in this period. Since 1966 there have been annual expeditions to Svalbard. In 1966 investigations were started in the Kongsfjord area on Brøggerbreen, and a year later on Lovenbreen. Both accumulation and ablation have been measured every year since by the direct glaciological method: snow sounding profiles, pits and stake readings. Accumulation maps have been drawn on the basis of the soundings. Accurate surveys of the ablation stakes have been carried out regularly to get longitudinal surface profiles for control of the mean net balance.

Soviet glaciologists started systematic annual massbalance measurements in 1966 on Vöringbreen in Grønfjorden. In the years 1973-76 they extended the program to three other glaciers on central west Spitsbergen and one on the east coast (Fig. 1).

\section{RESULTS FROM BRØGGERBREEN AND LOVÉNBREEN}

\section{Winter accumulation}

Precipitation in Svalbard is normally small. At the meteorological stations it used to be $200-400 \mathrm{~mm} \mathrm{a}^{-1}$ with maximum in August/September and minimum in April-June (Steffensen, 1982). Reliable measurements of precipitation are difficult because most of it comes in connection with strong winds and snow drifts. In $\mathrm{Ny}$-Ảlesund the meteorological station is situated only $5-6 \mathrm{~km}$ from the central area of the glaciers. However, the correlation between measured winter precipitation from September to June at the station and snow accumulation measured by sounding profiles over the entire glacier surface is low. During the 14-year period $1974-75$ to $1987-88$ the correlation coefficient was 0.63

Mean winter accumulation on Brøggerbreen during the period $1967-88$ is $0.71 \pm 0.16 \mathrm{~m}$ in water equivalent and on Lovénbreen $0.73 \pm 0.18 \mathrm{~m}$. As can be seen in Figure 2 and Table I, annual variations are fairly small.

Altitudinal variations of the accumulation and the distribution of the snow cover are shown on the accumulation map from Lovenbreen in Figure 3. On the lower part of the glaciers it was $0.40-0.50 \mathrm{~m}$ increasing up

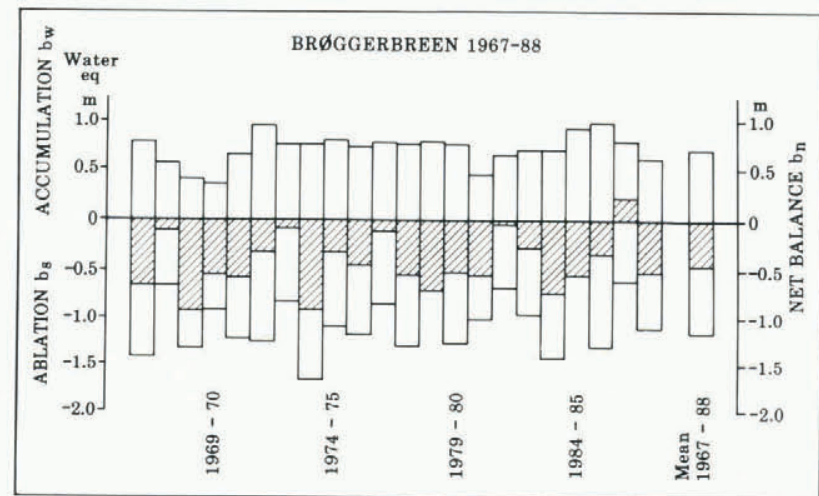

Fig. 2. Mass-balance results on Brøggerbreen in the period 1967-88. The hatched areas represent the net balance.

to $0.90-1.0 \mathrm{~m}$ in the highest areas. That is a close to constant gradient $\mathrm{d} b_{\mathrm{w}} / \mathrm{d} z \approx 1 \mathrm{~kg} \mathrm{~m}^{-2} \mathrm{~m}^{-1}$.

In addition to the snow precipitation measured on the stakes superimposed ice gives a significant additional accumulation. Superimposed ice is formed at the snow-ice interface when mild weather or rain soak the snow. This may happen after the first snow fall during the autumn and during the whole summer. The amount of this superimposed ice comes as an additional accumulation and was 0.10 to $0.20 \mathrm{~m}$ on average (Liestøl, 1975; Wold, 1976), i.e. $10-30 \%$ of the total snow accumulation.

Trend analysis of the measured winter balance shows stable conditions or a very slight increase of the winter accumulation.

\section{Summer ablation}

During the observation period (1967-88) the mean summer balance has been $1.14 \pm 0.29 \mathrm{~m} \mathrm{year}^{-1}$ water equivalent on Brøggerbreen and $1.08 \pm 0.30 \mathrm{~m}$ on Lovénbreen. Ablation values show more fluctuations than winterbalance values. Melting correlates well with summer balance $\left(b_{\mathrm{s}}=\mathrm{m} \mathrm{year}^{-1}\right.$ equivalent $)$ as a function of the mean temperature for June, July, and August $\left(t_{6-8}={ }^{\circ} \mathrm{C}\right)$ gives:

$$
b_{\mathrm{S}}=0.3674 \cdot t_{6-8}-0.163 \text { with } r=0.75 \text {. }
$$

TABLE I. SPECIFIC MASS BALANCE IN m/YEAR WATER EQUIVALENT AND ANNUAL EQUILIBRIUM LINE (ELA) FOR AUSTRE BRØGGERBREEN AND MIDTRE LOVÉNBREEN 1967-88

Austre Brøggerbreen

$\begin{array}{lllllllll}\begin{array}{c}\text { Balance } \\ \text { year }\end{array} & b_{\mathrm{w}} & b_{\mathrm{S}} & b_{\mathrm{n}} & & b_{\mathrm{w}} & b_{\mathrm{S}} & b_{\mathrm{n}} & \\ 1966-67 & & & & \text { ELA } & & & & \text { ELA } \\ 1967-68 & 0.77 & 1.42 & -0.65 & & & & & \\ 1968-69 & 0.57 & 0.67 & -0.10 & 295 & 0.48 & 0.51 & -0.03 & 295 \\ 1969-70 & 0.40 & 1.33 & -0.93 & 650 & 0.41 & 1.25 & -0.84 & 650 \\ 1970-71 & 0.37 & 0.91 & -0.54 & 490 & 0.36 & 0.89 & -0.53 & 500 \\ 1971-72 & 0.65 & 1.23 & -0.58 & 400 & 0.70 & 1.16 & -0.46 & 385 \\ 1972-73 & 0.95 & 1.26 & -0.31 & 360 & 0.98 & 1.20 & -0.22 & 350 \\ 1973-74 & 0.74 & 0.82 & -0.08 & 270 & 0.82 & 0.84 & -0.02 & 310 \\ 1974-75 & 0.75 & 1.67 & -0.92 & 550 & 0.70 & 1.59 & -0.89 & 550 \\ 1975-76 & 0.78 & 1.09 & -0.31 & 340 & 0.83 & 1.04 & -0.21 & 340 \\ 1976-77 & 0.72 & 1.17 & -0.45 & 410 & 0.75 & 1.10 & -0.35 & 420 \\ 1977-78 & 0.76 & 0.87 & -0.11 & 320 & 0.80 & 0.84 & -0.04 & 300 \\ 1978-79 & 0.75 & 1.31 & -0.56 & 410 & 0.81 & 1.29 & -0.48 & 420 \\ 1979-80 & 0.77 & 1.48 & -0.71 & 550 & 0.80 & 1.46 & -0.66 & 480 \\ 1980-81 & 0.75 & 1.27 & -0.52 & 430 & 0.83 & 1.26 & -0.43 & 415 \\ 1981-82 & 0.46 & 1.01 & -0.55 & 450 & 0.51 & 0.97 & -0.46 & 435 \\ 1982-83 & 0.64 & 0.68 & -0.04 & 280 & 0.66 & 0.64 & 0.02 & 290 \\ 1983-84 & 0.70 & 0.97 & -0.27 & 345 & 0.75 & 0.92 & -0.17 & 330 \\ 1984-85 & 0.69 & 1.42 & -0.73 & 500 & 0.74 & 1.42 & -0.68 & 440 \\ 1985-86 & 0.93 & 1.48 & -0.55 & 450 & 0.98 & 1.46 & -0.48 & 445 \\ 1986-87 & 0.98 & 1.30 & -0.32 & 380 & 1.06 & 1.27 & -0.21 & 370 \\ 1987-88 & 0.82 & 0.60 & +0.22 & 200 & 0.82 & 0.58 & +0.24 & 225 \\ & 0.61 & 1.13 & -0.52 & 440 & 0.56 & 1.05 & -0.49 & 425 \\ 1967-88 & & & & & & & & \\ & 0.71 & 1.14 & -0.43 & (417) & 0.73 & 1.08 & -0.35 & (399)\end{array}$

Midtre Lovénbreen 


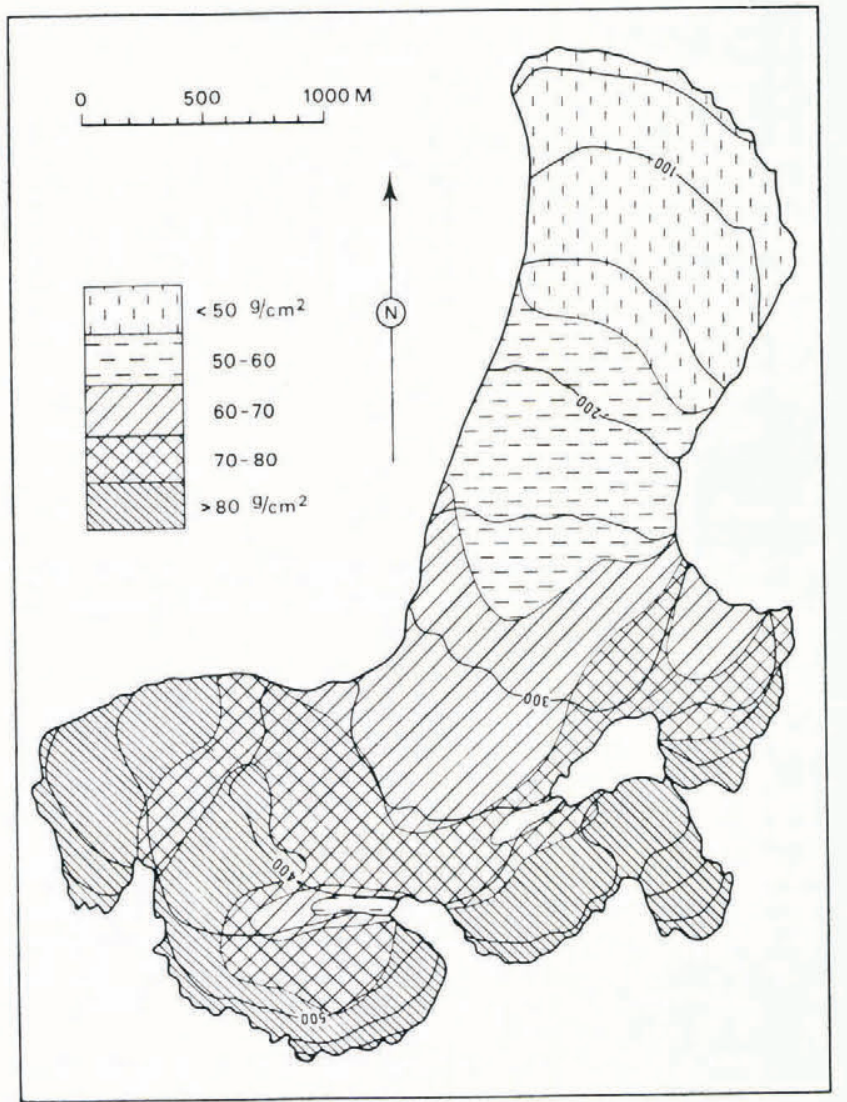

Fig. 3. Distribution of snow accumulation on Lovénbreen in a year with average precipitation.

If we introduce melting degree days (MDD), the cumulative sum of daily above freezing mean temperatures, for the whole summer season we get a larger correlation coefficient and better regression equation:

$$
b_{\mathrm{S}}=0.0046 \cdot \mathrm{MDD}_{6-9}-0.6259 \text { with } r=0.88 \text {. }
$$

As can be seen from the altitudinal variations of the net balance (Fig. 4) the ablation near the snout of the glaciers is very high. In the level $100-150 \mathrm{~m}$ a.s.l. the ablation is twice as high as in the level $200-250 \mathrm{~m}$. Wind drift causes low accumulation on this part of the glaciers and thus low albedo early in the melt season. In addition the lower parts of both glaciers are exposed to prevailing wind transport in and out the fjord in the main valley.

There is no sign of increased melting. The trend for the whole period is very stable. Further statistical analysis of the mass-balance data versus climatic factors are given in Lefauconnier and Hagen (this volume).

\section{BRØGGERBREEN 1966-88}

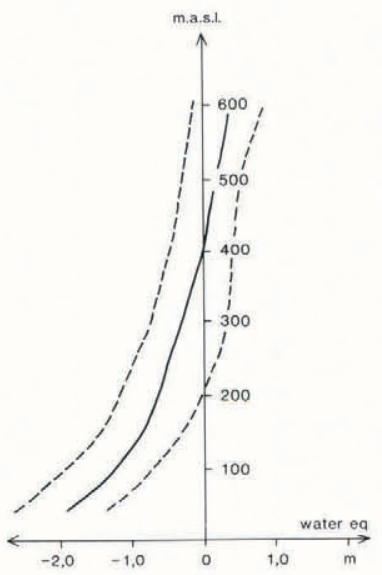

LOVĖNBREEN 1966-88

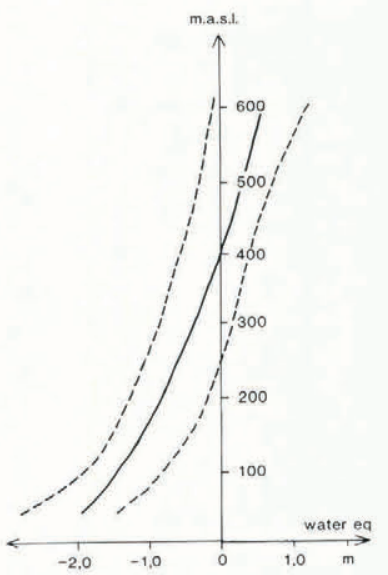

Fig. 4. Mean net mass-balance variations related to altitude on Brøggerbreen and Lovénbreen. Most extreme years are dotted.

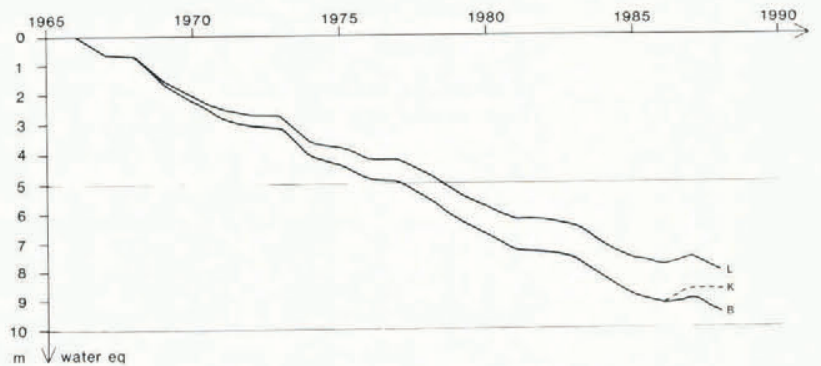

Fig. 5. Cumulative mass-balance on Brøggerbreen (B) and Lovénbreen (L) 1967-88; Kongsvegen (K) 1987-88.

\section{Net balance}

The glaciers are not in balance with the existing climate; summer ablation has been greater than winter accumulation nearly all observed years, resulting in steady decreasing ice masses. Annual values for both glaciers are given in Table I and illustrated for Brøggerbreen in Figure 2 . The mean annual specific net mass balance is $-0.46 \mathrm{~m}$ water equivalent on Brøggerbreen and $-0.37 \mathrm{~m}$ on Lovénbreen.

Cumulative net balances are shown in Figure 5. The total mass loss since the balance year $1967-68$ was $54 \times$ $10^{6} \mathrm{~m}^{3}$ and $40.5 \times 10^{6} \mathrm{~m}^{3}$ respectively, which corresponds to an average lowering of the surface of 8.9 and $7.5 \mathrm{~m}$. That is more than $10 \%$ of the total volumes.

Only one balance year, 1986-87, had positive net balance during these twenty years, respectively $+0.22 \mathrm{~m}$ and $+0.24 \mathrm{~m}$ for the two glaciers, due to the extraordinary cold summer of 1987.

Based on air photographs from 1977, a glacier map was constructed on the scale $1: 20000$ with contour intervals $10 \mathrm{~m}$. One of the stakes was surveyed in 1985 . The vertical difference at this point of the glacier surface was then $5.20 \mathrm{~m}$ from 1977 to 1985 . The measured cumulative net balance during the same period was $4.95 \mathrm{~m}$ in water equivalents which is $5.50 \mathrm{~m}$ of ice. The direct measurements on the map thus agree well with the sum of the annual mass-balance figures.

Ice-mass transport down the glacier is much less than ablation in the lower part. Thus the surface gradient gets steeper year by year. This may result in a surge after some years.

\section{RESULTS FROM FINSTERWALDERBREEN}

In the years 1950 to 1968 the Finsterwalderbreen was visited every second year. It was therefore only possible to obtain balances for two-year periods. The measurements were finished in the middle of August. Melting at the end of the ablation periods is therefore added to the following two years' balance. The results are given in Table II.

Only two of the periods show positive balance; the result was therefore a decrease of the glacier volume. The mean annual deficit was $-0.25 \mathrm{~m}$ water equivalent, which gives a total loss of $-4.55 \mathrm{~m}$ from 1950 to 1968. As the velocity below $300 \mathrm{~m}$ a.s.l. is negligible, the lowering of the surface here is almost the same as the net balance.

In the balance year 1973-74 winter and summer balance were measured in addition to the net balance. The result was: $b_{\mathrm{w}}=0.92 \mathrm{~m}, b_{\mathrm{S}}=1.43 \mathrm{~m}$, and $b_{\mathrm{n}}=-0.51 \mathrm{~m}$.

TABLE II. NET MASS BALANCE ON FINSTERWALDERBREEN EVERY SECOND YEAR FROM 1950-52 TO 1966-68 GIVEN IN m a ${ }^{-1}$ EQUIVALENT

Balance years Net balance $\left(\mathrm{m} \mathrm{a}^{-1}\right)$

$\begin{array}{ll}1950-52 & -1.35 \\ 1952-54 & +0.05 \\ 1954-56 & -1.20 \\ 1956-58 & +0.20 \\ 1958-60 & -0.05 \\ 1960-62 & -1.15 \\ 1962-64 & -0.10 \\ 1964-66 & -0.40 \\ 1966-68 & -0.55\end{array}$


$\begin{array}{llll}\text { Vöringbreen } & \text { Blacier } & & \\ \text { Longyearbreen } & \text { Bertilbreen } & \text { Daudbreen }\end{array}$

\begin{tabular}{|c|c|c|c|c|c|c|c|c|c|c|c|c|c|c|c|}
\hline $\begin{array}{l}\text { Balance } \\
\text { year }\end{array}$ & $b_{\mathrm{w}}$ & $b_{\mathrm{S}}$ & $b_{\mathrm{n}}$ & $b_{\mathbf{w}}$ & $b_{\mathrm{s}}$ & $b_{\mathrm{n}}$ & $b_{\mathbf{w}}$ & $b_{\mathrm{S}}$ & $b_{\mathrm{n}}$ & $b_{\mathrm{w}}$ & $b_{\mathrm{S}}$ & $b_{\mathrm{n}}$ & $b_{\mathrm{w}}$ & $b_{\mathrm{S}}$ & $b_{\mathrm{n}}$ \\
\hline $\begin{array}{l}1966-67 \\
.\end{array}$ & 87 & 107 & -20 & & & & & & & & & & & & \\
\hline $1973-74$ & 64 & 180 & -116 & & & & & & & & & & & & \\
\hline $1974-75$ & 73 & 99 & -26 & 57 & 57 & 0 & & & & & & & & & \\
\hline $1975-76$ & 44 & 161 & -117 & & & -20 & & & & 34 & 106 & -72 & 72 & & \\
\hline $1976-77$ & 62 & 75 & -13 & 62 & 88 & -26 & 57 & 99 & -42 & 48 & 107 & -59 & & & \\
\hline $1977-78$ & 50 & 166 & -116 & 34 & 115 & -81 & 45 & 118 & -73 & 44 & 144 & -100 & 69 & 135 & -66 \\
\hline $1978-79$ & 54 & 143 & -89 & 61 & $168-$ & -107 & 48 & 171 & -123 & 50 & 135 & -85 & 54 & 112 & -58 \\
\hline $1979-80$ & 55 & 105 & -50 & 48 & 113 & -65 & 50 & 119 & -69 & 31 & 123 & -92 & 67 & 124 & -57 \\
\hline $1980-81$ & 49 & 143 & -94 & 56 & 92 & -36 & 49 & 82 & -33 & 42 & 108 & -66 & 69 & 81 & -12 \\
\hline $1981-82$ & 50 & 52 & -2 & 38 & 13 & +25 & 41 & 29 & +12 & 34 & 51 & -17 & 49 & 37 & +12 \\
\hline $1982-83$ & 60 & 113 & -53 & 48 & 78 & -30 & & & & 41 & 88 & -47 & & & -10 \\
\hline $1983-84$ & 70 & 180 & -110 & 62 & 123 & -61 & & & & 43 & 146 & -103 & & & \\
\hline $1984-85$ & 76 & 121 & -45 & 54 & 111 & -57 & & & & 44 & 141 & -97 & & & \\
\hline $1985-86$ & 70 & 126 & -56 & & & -60 & & & & & & & & & \\
\hline Mean & 62 & 127 & -65 & 52 & 96 & -43 & 48 & 103 & -55 & 41 & 115 & -70 & 63 & 98 & -32 \\
\hline
\end{tabular}

\section{RESULTS FROM SOVIET MEASUREMENTS}

Soviet mass-balance investigations are given in Table III (Gus'kov, 1983; personal communication from Troitskiy). Locations of these glaciers can be seen in Figure 1. The series are shorter but the results are in fairly good agreement with the Norwegian recordings. Their longest series from Vöringbreen shows a correlation coefficient $r=$ 0.81 with the net balance of Brøggerbreen, while the net balance of Bertilbreen gives $r=0.88$. On both these glaciers the results show high mass deficit than in the Kongsfjord area. The mean net balance on Vöringbreen was $-0.65 \mathrm{~m}$ in the period $1973-74$ to $1985-86$ while it was $-0.70 \mathrm{~m}$ on Bertilbreen in the observation period 1975-76 to 1984-85. The five years of measurements on the small glacier Daudbreen on the east coast indicate that glaciers in the east have negative mass balance too, and follow the same trends as the central and westerly glaciers.

\section{DISCUSSION}

\section{ELA and net balance}

The activity index is the balance gradient near the equilibrium line. This index $\left(\delta b_{n} / \delta z\right)$ is nearly constant for each glacier and thus gives a strong relationship between the net balance $\left(b_{n}\right)$ and the $\operatorname{ELS}\left(\mathrm{z}_{\text {ela }}\right)$. This has been shown on different temperate glaciers elsewhere, e.g. on Storbreen in Norway (Liestøl, 1967), Storglaciären in Sweden (Schytt, 1981), and Peyto Glacier in Canada (Young, 1981). Kuhn (1981) stated that, for a given glacier, climatic fluctuations can best be traced from observations of variations in the equilibrium-line altitude. A simple regression analysis gave the linear equation for Brøggerbreen:

$$
b_{\mathrm{n}}=0.649-0.002637 \cdot z_{\text {ela }} \text { with } r=0.961
$$

and for Lovénbreen:

$$
b_{\mathrm{n}}=0.9158-0.003223 \cdot z_{\text {ela }} \text { with } r=0.953
$$

Both lines are shown in Figure 8.

The measurements showed that the mean ELA is $417 \mathrm{~m}$ a.s.l. on Brøggerbreen and $399 \mathrm{~m}$ a.s.1. on Lovénbreen during the 20 years of observations.

Equations (3) and (4) give equilibrium lines for zero net balance at 246 and $284 \mathrm{~m}$ a.s.1., respectively (Fig. 6).

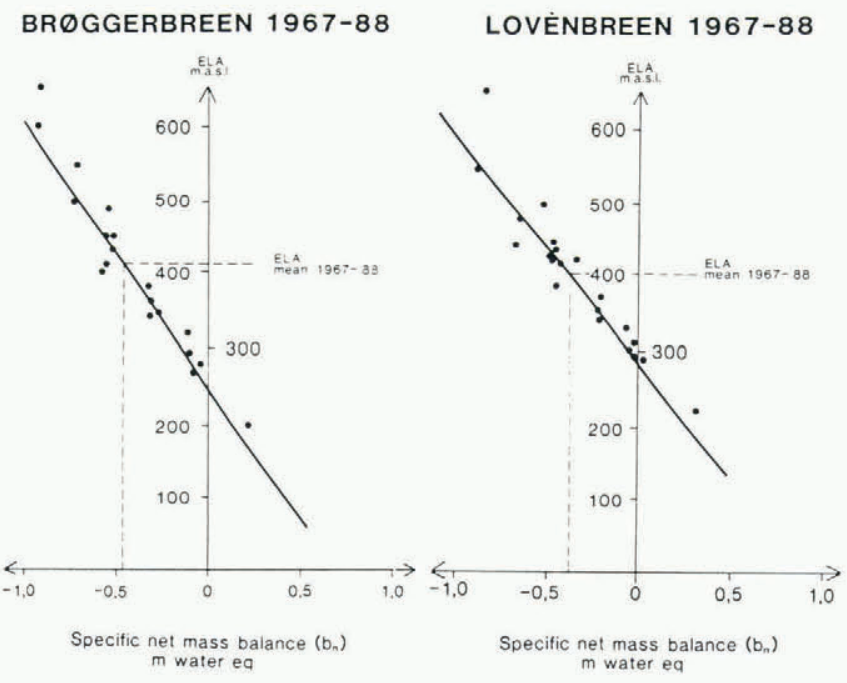

Fig. 6. The relation between the equilibrium-line altitude and the specific net mass balance on Brøggerbreen and Lovénbreen.

This balance could be obtained if the MDD sum was lowered from 390 to 290, which corresponding to a lowering of mean summer temperature by about $18 \mathrm{C}$. The same balance could be obtained by about $50 \%$ high winter precipitation.

When the snow pack is melting away the superimposed ice is visible in the zone below the transient snow line. The altitude of the transient snow line may be far above the actual ELA, and the altitude difference varies as the amount of superimposed ice varies. Thus we need stake readings to find the elevation of the equilibrium line. When this elevation is found the net balance of the glacier can be calculated from the regression Equations (3) and (4).

Net balance was a little less negative on Lovénbreen than on Brøggerbreen. This is probably mainly because the average elevation is a little higher on Lovénbreen, $340 \mathrm{~m}$ a.s.1. versus $310 \mathrm{~m}$ a.s.l. Thus the winter accumulation is slightly higher and the summer ablation slightly lower.

Both the Norwegian and the Soviet mass-balance measurements, except on Finsterwalderbreen $\left(33.8 \mathrm{~km}^{2}\right)$, have been carried out on relatively small $\left(c .6 \mathrm{~km}^{2}\right)$ glaciers close to the coast. The main parts of these glaciers are below 


\section{KONGSVEGEN/BRøGGERBREEN 1988}

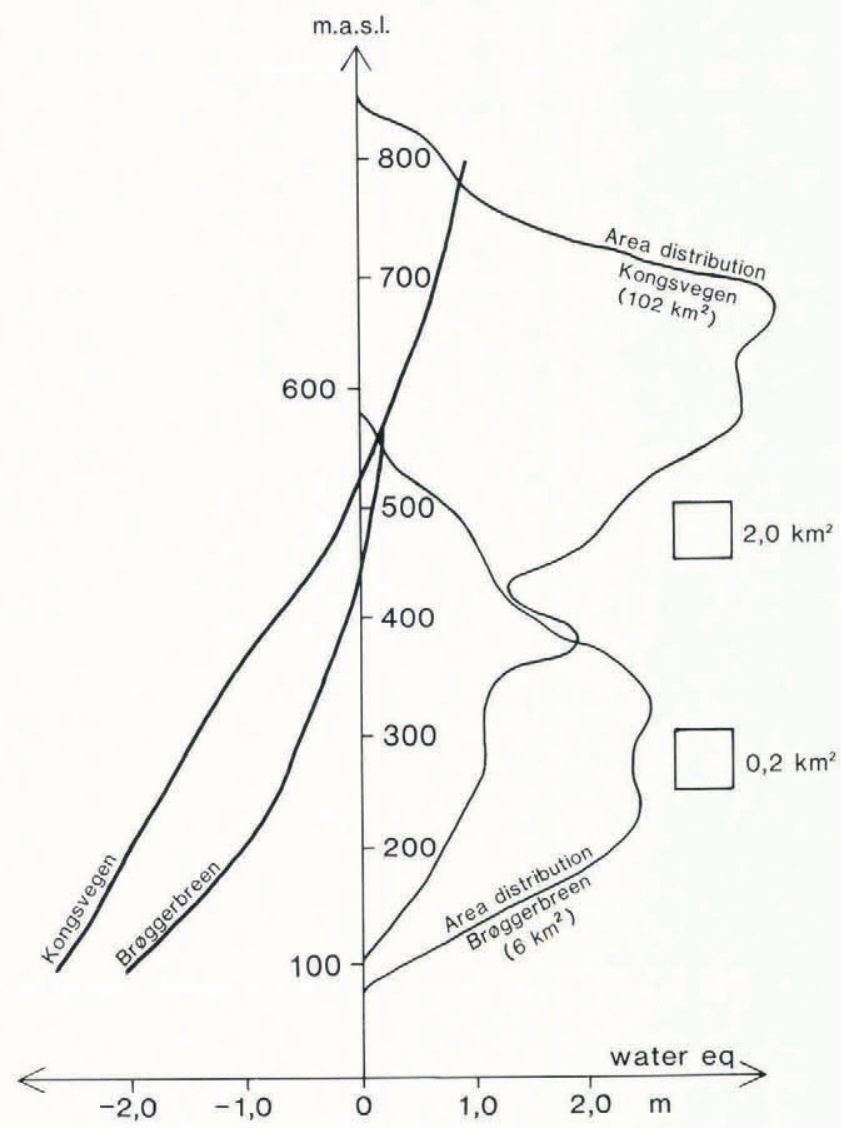

Fig. 7. The net balance and area distribution versus altitude on Brøggerbreen and Kongsvegen. Note the different scale for the areas.

$500 \mathrm{~m}$ a.s.l. On large glaciers and ice caps only sporadic measurements have been carried out for single years. Recent investigations on Kongsvegen (Hagen, 1988) indicate that these glaciers covering higher areas are closer to steadystate balance than the small ones. In the balance year 198788 the net balance on Kongsvegen was $-0.05 \mathrm{~m}$ while it was $-0.50 \mathrm{~m}$ on Brøggerbreen. The equilibrium-line altitude was at $520 \mathrm{~m}$ and at $450 \mathrm{~m}$. The importance of the area distribution can be seen from Figure 7. The mean altitude on Brøggerbreen is $310 \mathrm{~m}$ a.s.1. while it is $560 \mathrm{~m}$ a.s.l. on Kongsvegen.

\section{The climate}

Temperature recordings in Svalbard started at Green Harbour in 1912. The most striking in this series is the rapid increase of winter temperature from 1912 to 1920.

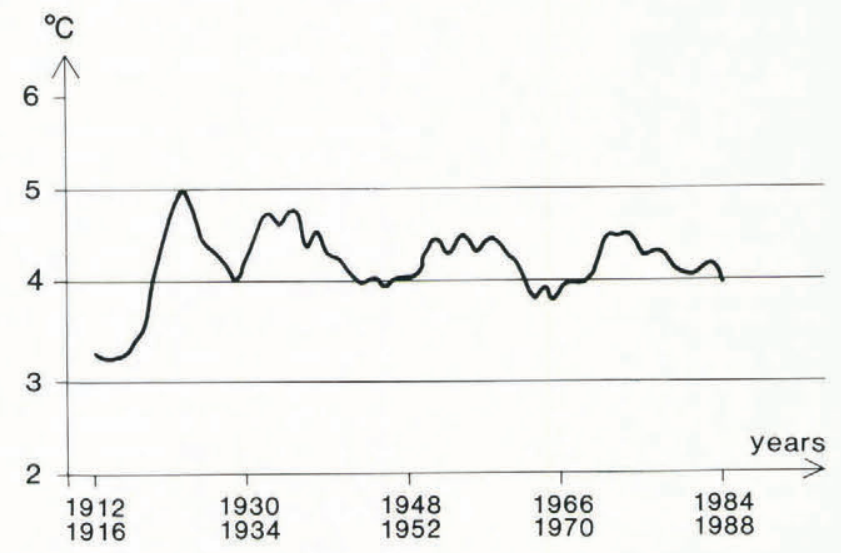

Fig. 8. Reconstructed running five-year mean summer temperature for July, August, and September in Longyearbyen, Svalbard 1912-88.
This is in good agreement with recordings in northern Scandinavia and the northern hemisphere. The summer temperature increase in 1912-20 however was less pronounced. The five-year running mean summer temperature (July-September) in Longyearbyen has been fairly stable since 1920 and fluctuated between $4^{\circ}$ and $4.5^{\circ} \mathrm{C}$ (Fig. 8).

The greenhouse climate effect is expected to increase the global temperature during the next decade. In polar regions this effect is expected to be largest and possibly first observable. Different models all conclude with a temperature increase of $6^{\circ}$ to $8^{\circ} \mathrm{C}$ in polar regions within 40 years. Even with the lowest expected increase this means $+0.15^{\circ} \mathrm{C}$ per year.

Increased temperature results in higher evaporation and thus higher precipitation. On a global scale some models predict this effect to cause $7-11 \%$ higher annual precipitation within the next 40 years, mainly in the tropics. However, an increase of about $5 \%$ of the winter precipitation in the Svalbard area will compensate only for a mean increase of the summer temperature of about $0.1^{\circ} \mathrm{C}$. Higher evaporation will increase the cloudiness and thus decrease the short wave incoming radiation and increase the long wave radiation balance.

Increased glacier melting is one of the easiest measurable effects of temperature rise. However, many climate models predict annual temperature increase and less seasonal temperature differences. An increase in the winter temperature has a minor effect on the summer ablation. The main effect of a temperature increase on the glaciers is thus the increase in the summer temperature, or the total MDD sum.

As far as we can see from twenty years of massbalance measurements in north-west Spitsbergen there is no indication of increased mass loss/melting rate on the glaciers. The glaciers have had a steady decrease in volume with negative net balance nearly all years. The only trend is a slightly lower negative net balance due to a small increase of the winter accumulation.

\section{REFERENCES}

Gus'kov, A.S. 1983. Vodno-ledovy balans lednikov Shpitsbergena v 1979/80 balansovom goda [Water-ice balance of glaciers of Spitsbergen in the 1979/80 balance year]. Materialy Glyatsiologicheskikh Issledovaniy. Khronika. Obsuzhdeniya 46, 136-139.

Haeberli, W. and P. Müller, comps. 1988. Fluctuations of glaciers 1980-1985. (Vol. V.) Zürich, World Glacier Monitoring Service.

Hagen, J.O. 1988. Glacier mass balance investigations in the balance year 1986-87. Polar Res., 6(2), 205-209.

Kuhn, M. 1981. Climate and glaciers. International Association of Hydrological Sciences Publication 131 (Symposium at Canberra 1979 - Sea Level, Ice and Climatic Change), 3-20.

Lefauconnier, B. and J.O. Hagen. 1990. Glaciers and climate in Svalbard; statistical analysis and reconstruction of the Brøgger glacier mass balance for the last 77 years. Ann. Glaciol., 14, 148-152.

Liestøl, O. 1967. Storbreen glacier in Jotunheimen, Norway. Nor. Polarinst. Skr. 141.

Liestøl, O. 1975. Glaciological work in 1973. Nor. Polarinst. Árbok 1973, 181-192.

Liestal, O. 1977. Pingos, springs, and permafrost in Spitsbergen. Nor. Polarinst. Arbok 1975, 7-29.

Schytt, V. 1981. The net mass balance of Storglaciären, Kebnekaise, Sweden, related to the height of the equilibrium line and to the height of the $500 \mathrm{mb}$ surface. Geogr. Ann., 63A(3-4), 219-223.

Steffensen, E.L. 1982. The climate at Norwegian Arctic stations. Klima (Norsk Meteorologisk Institutt) 5 .

Wold, B. Unpublished. En glasiologisk undersøkelse av Austre Brøggerbre, Spitsbergen. (Thesis, Oslo Universitet, 1976.)

Young, G.J. 1981. The mass balance of Peyto Glacier, Alberta, Canada, 1965 to 1978. Arct. Alp. Res., 13(3), 307-318. 